\title{
Hálózati szerveződés az „új gazdaságban” a világgazdaság centrumában és azon kívül
}

A cikk az értéklánc-alapú hálózatosodást veszi nagyító alá. Az első fejezet arra a kérdésre keresi a választ, hogy az információs technológiai forradalom elôsegítette-e, hogy a világgazdaság centrumán kívül fekvő országok gazdasági szereplői globális hálózatokba integrálódjanak. A második fejezet rámutat arra, hogy bár a világgazdaság centrumán kívül fekvő néhány ország sikeres hálózatosodásos modernizációt hajtott végre, gazdasági szereplőik globális vállalati hálózatokba integrálódtak; a hálózati szerveződés az ô esetükben mégsem vezetett az új üzleti modell vállalati-hálózataira jellemző, minőségi jegyek kialakulásához, a kooperatív, bizalomra és kölcsönösségre épülő, kevéssé hierarchikus, horizontális szerveződésủ kapcsolatok térhódításához.

\section{Szerzői információ:}

\section{Szalavetz Andrea}

a MTA Világgazdasági Kutatóintézet tudományos főmunkatársa. Jelenlegi kutatási területe az „új gazdaság” elmélete, illetve az a kérdés, hogy ezen elméleti tételek milyen mértékben alkalmazhatók a világgazdaság központján kívül fekvő, információtechnológiai hardver gyártására szakosodott felzárkózó országokra.

Korábbi kutatásait összegző, az innovációs gazdaságtan témakörében megjelent könyvei:

Technológiatranszfer, innováció és modernizáció. OMFB, Budapest, 1999

Hagyományos iparágak - Hanyatló iparágak? Oktatási Minisztérium, Budapest, 2000 
Szalavetz Andrea:

\section{Hálózati szerveződés az „új gazdaságban” - a világgazdaság centrumában és azon kívül*}

\section{Bevezetö}

Az „új gazdaság” új üzleti modell értelmezése ${ }^{1}$ azt mondja ki, hogy az információtechnológiai forradalom következtében megváltozott az üzleti környezet. A vállalati versenyképességet és az üzleti sikert új versenyfeltételek, a korábbiaktól eltérő tényezốk határozzák meg. A vállalatok és a kereskedelembe kerülő javak értékének egyre nagyobb része olyan immateriális tényezóktől függ, mint például a K+F-bázis minősége, licencek, márkanevek, vevốkapcsolatok, disztribútori hálózat, innovatív humán erőforrások, különleges vállalatszervezeti- és menedzsment-megoldások, stb. A tudás a fizikai tôkénél fontosabb termelési inputtá vált.

Árulkodó a szóhasználat: a nemzetközi üzleti- és menedzsment-irodalomban a tudást ugyanazokkal a kategóriákkal elemzik, mint az egyéb vállalati produktív inputokat. A korábban elterjedt "flow” jellegú elemzési kategória, a „tudásáramlás” mellett, meghonosodott a „stock” kategória is: a tudás „állománya”. Elemzésekben gyakran szerepel a „tudás amortizációja" kifejezés, sôt szakcikkek születnek a tudás életciklus-menedzsmentjéröl (Birkinshaw \& Sheehan, 2002). A szerzôdéses vállalatelméletek ${ }^{2}$ és az evolúciós, kompetencia alapú vállalatelméletek ${ }^{3}$ mellett megjelent és gyors népszerüségre tett szert eg̉y újabb egydimenziós elmélet (Kapás, 1999): a tudás alapú vállalatelmélet (Nonaka \& Takeuchi 1995; Nonaka és szerzôtársai, 2000), amely a vállalat létének alapvetố magyarázataként és egyúttal a vállalati versenyképesség legfontosabb tényezójeként határozza meg̉ a tudás termelését.

Az új üzleti modell egyik alapvetô jellemvonása a gazdaság hálózati szervezôdése. Verseny ma már nem csupán termékek és cégek dimenziójában mutatkozik, hanem hálózati szinten. Az egyéni stratégia, egyéni hatékonyság ${ }^{4}$ háttérbe szorult a versenyképességet magyarázó tényezók sorában, a versenyképességet egyre inkább a kollektí hatékonyság, a hálózati hatékonyság határoz:a meg. Hálózatok versengenek egymással, amelyekben olyan paraméterek, mint a komplementer termékek és szolgáltatások elérhetősége és változatossága, vagy a hálózat mérete, kiterjedése, a vevôk számára gyakran fontosabbak, mint maguk a termékparaméterek.

Mindez jól tükröződik abban, hogy vállalati elemzók a vállalat kapcsolati hálózatának minőségi paramétereit ma már a versenyképességet meghatározó egyik legfontosabb stratégiai tényezônek tartják. Az ágazati elemzốk ugyanakkor ma már nem az egyes vállalatokat, az iparágak „trend-alakító” szereplőit, hanem a vállalati hálózatokat tekintik elemzési egységnek (Castells, 2000). A hálózati kapcsolatok minôsége és a vállalati teljesítmény közötti szoros összefüggésre utal a „hálózati kompetencia” elem- 
zési kategóriájának megjelenése a menedzsment szakirodalomban. (Lorenzoni \& Lipparini, 1999)

A kulcskompetencia ${ }^{5}$ (core competence) kifejezést Prahalad és Hamel (Prahalad \& Hamel, 1990) cikke vezette be a köztudatba. Kompetencia alatt a vállalatoknak azt a képességét értjük, hogy bizonyos tevékenységeket elvégezzenek - felismerjenek; mobilizáljanak és kiaknázzanak bizonyos erôforrásokat válaszul a kinálkozó üzleti lehetôségekre. A nemzetközi menedzsment-sæakirodalom a vállalati kompetenciák közül föként a technológiai kompetenciával, a vállalat sæámára legkedvezóbb technológia felismerésének, megvásárlásának és abszorpciójának, vagy ki-és továbbfejlesstésének képességével foglalkozott. Késóbb a vizsgálatok kibövültek a menedzsment kompetencia egyyes elemeivel: a marketingés a szervezet-kialakítási kompetenciával. Eะ utóbbi két kompetencia-típusnak aะ új ü:leti modellek elemzói eǵy új, közös elnevezést adtak és leszögezték: az „új gazdaság” időszakában a vállalati versenyképesség kulcsává a hálózati kompetencia vált. (Ritter \& Gemünden, 2003)

Korábban, a marketing-kompetencia vizsgálatakor még kizárólag arról szóltak az elemzések, hog̉y képes-e eg̉y vállalat meğfeleló számú vevốt megsszerezni, meǵfelelő méretú piacot meghódítani. A stratégiai elemzésekben a vevóket egydimenziósan, kizárólag fogyasztóként, vásárlóként vizsgálták, de figyelmen kivül hagyták a vevoóknek az innovációk létrehozásában játszott szerepét. Hasonlóan egydimenziós volt az értéklánc-kialakitási képességet és értéklánc-menedzsmentet kompetenciaként vizsgáló elemzések fókusza: az értékelés költség-és stratégiai szempontokat (pl. rugalmasság) vett alapul, ugyanakkor, a beszállitókat nem tekintették tudás- és információs bá:isnak, sem tevóleges résঞtvevoóknek a rendszerként felfogott termékeik fejlesztésében. A hálózati kompetencia fogalma és elemzési fókusঞa kiküsæöbölte ezeket a hiányosságokat. Ma már nem csupán a menedzsmentszakirodalom szerzői i, de maǵuk a vállalatok is az „extended enterprise” (meghosszabbított vállalat) kategóriájában gondolkodnak, vagyis a kompetencia-forrásaik feltárásakor (ön)elemzésük tárgyya nem korlátozódik magára a (globális) vállalatra, illetve a leányvállalati körre, hanem magában foglalja a beszállitókat, vevóket, befektetóket és egyyéb partnereket is, vagyis a vállalati hálózatot. (Prahalad \& Ramaswamy, 2000)

A gazdasági szereplők hálózati szerveződését, mint a piac és a hierarchia közötti harmadik koordinációs forma (Powell, 1990) súlyának növekedését leginkább a vállalati tevékenységek növekvő tudás- és K+F-igényessége mozdította elő. A kutatásfejlesztés minden korábbinál költségesebbé és kockázatosabbá vált, a technológiai ciklusok egyre rövidebbé. Egy-egy termék előállításához egyre komplexebb technológiai tudásra van szükség, a tudásfelhalmozódás ütemével pedig sok esetben csak úgy lehet lépést tartani, ha a cégek egy-egy tudáselemre specializálódnak. Így a vállalatok a tevékenységükhöz szükséges tudás egyre nagyobb részét kívülról, specializált cégektől kénytelenek megszerezni. Elemzôk már a kilencvenes évtized elején felfigyeltek a stratégiai technológiai kapcsolatok számának látványos növekedésére, és ezt a kapitalizmus új vonásaként, szövetségi kapitalizmusként írták le. (Hagedoorn, 1993; Dunning, 1995)

A hálózati szervezôdésnek két további jelenség adott új lendületet az utóbbi évtizedben. Az egyik, az erôsödő vertikális dezintegráció (Szabó, 1998), vagyis a korábban vállalatokon belül integrált tevékenységek növekvô részének kihelyezése, a má- 
sik pedig a tudásalapú szolgáltatások növekvố gazdasági szerepe, illetve magának a feldolgozóiparnak a tercierizálódása (Szalavetz, 2002.b). A feldolgozóipar tercierizálódása a vállalati mûködéshez kapcsolódó szolgáltatások növekvô súlyát, illetve a termékekhez kapcsolódó, a fogyasztók számára nyújtott szolgáltatások egyre szélesedő körét jelenti. A stratégiai üzleti szolgáltatások diverzifikálódásával a feldolgozóipari termékek értékláncai egyre komplexebbé váltak. Mivel a vállalatok egyre több szolgáltatást vásárolnak külsô, specializált szolgáltatóktól, a kereskedelembe kerülô szolgáltatások száma gyors növekedésnek indult (OECD, 1999), a feldolgozóipari hálózatokba egyre nagyobb számban kapcsolódtak be szolgáltatók is.

Három hálózati szervezôdés-típust különböztetünk meg: (1) a komplex rendszerként felfogható termékeknek, illetve azok alrendszereinek, komponenseinek, továbbá a kapcsolódó termékeknek és szolgáltatásoknak ${ }^{6}$ elő́llítóit magában foglaló értékláncot, (2) a földrajzi alapú hálózati szerveződést: a klasztereket és (3) a stratégiai szövetségeket.

Ez a tanulmány az értéklánc-alapú hálózatosodást veszi nagyító alá. Az első fejezet arra a kérdésre keres választ, hogy vajon az információtechnológiai forradalom elôsegítette-e, hogy a világgazdaság centrumán kívül fekvô országok gazdasági szereplôi globális hálózatokba integrálódjanak. A fejezet bizonyítani igyekszik, hogy ezen országok világgazdasági nyitása mellett, az információtechnológiai forradalom a maga részérôl szintén hozzájárult, hogy mind több ország, mind több gazdasági szereplôje globális hálózatokba integrálódhasson.

A második fejezet ugyanakkor rámutat arra, hogy bár a világgazdaság centrumán kívül fekvô néhány ország sikeres hálózatosodásos modernizációt hajtott végre, gazdasági szereplőik globális vállalati hálózatokba integrálódtak, a hálózati szervezôdés az ô esetükben mégsem vezetett az új üzleti modell vállalati hálózataira jellemző minőségi jegyek kialakulásához, a kooperatív, bizalomra és kölcsönösségre épülö, kevéssé hierarchikus, horizontális szerveződésû́ kapcsolatok térhódításához.

A vizsgálat tárǵya elsốsorban Maǵyarország, de a megállapítások - eltérö erövel - azokra az országokra is érvényesek, amelyek növekedési teljesítménye, strukturális modernizációja nagyrésঞt a külföldi múködötőke-befektetések segítségével felfuttatott, technológia-igényes feldolgozóipari szektorokra (elsősorban informatikai feldolgozóiparra) vezethetö vis:sza. A felzárkózást széles értelemben tekintve ide sorolhatók az Európai Unió informatikai feldolgozóiparra specializálódó országai, például Írország, Hollandia (Finnország kevésbé, hiszen a finn informatikai szektorban nem a külföldi múködốtóke, hanem inkább a hazai tôke szerepe jelentős). Ebbe a körbe tartoznak továbbá az informatikai feldolgozóiparra specializálódott délkelet-ázsiai orsะágok (elsősorban Tajvan, Thaiföld, Szingapurr, Dél-Korea), továbbá Mexikó, Latin-Amerikában pedig a két leǵjobb példa Costa Rica és Chile.

\section{A felzárkózó országok szereplőinek integrálódása a globális hálózatokba}

A nemzetközi közgazdasági- és menedzsment irodalom egyik gyakran vizsgált témája a vállalati tevékenység fokozódó feldarabol(ód)ása az értéklánc mentén. A tanulmányok arra a kérdésre keresnek választ, hogy melyek ennek a folyamatnak a világgazdasági, technológiai, vállalatszervezeti és stratégiai következményei. Krugman (Krugman, 1996) az értéklánc felszeleteléséról ír, Feenstra (Feenstra, 1998) a termelési folyamat de- 
zintegrációjáról, a legtöbb elemző pedig vertikális specializációról, ${ }^{8}$ de függetlenül a terminológiától, mindnyájan statisztikai adatok sokaságával dokumentálják a gazdasági tevékenység növekvő szervezeti fragmentálódását.

Hipotézisünk szerint, a termelési folyamat dezintegrációja és a tudás kodifikálhatósága között szoros az összefüggés. A tudás kodifikálása megkönnyíti a munkamegosztást, hiszen ha a (rejtett) tudás információvá alakitható, a tudásátadásnak és az átadott tudással végzett tevékenység felügyeletének költségei csökkennek. A rejtett tudás kodifikálását lehetôvé tevô technológiák fejlődését vállalatszervezeti innovációk egészítették ki és ezek együttes hatása vezetett a termelési folyamat fokozódó dezintegrációjához.

Gondoljunk például a toyotizmusra, amelynek esetében a beszállítói hálózat bővítését (és struktúrájának átalakítását), a termelés növekvô részének kiszervezését és a rugalmas, karcsú termelési modell (lean production) meghonosítását a számítástechnika fejlődése tette lehetővé.

Az Internet megjelenése és az információtechnológia további ugrásszerû fejlôdése a tudás kodifikálásának újabb nagy hullámát indította el. A feldolgozóipari munkafolyamatok egy része és a vállalati múködéshez kapcsolódó adminisztratív tevékenységek nagy része a kodifikálás révén rutinszerúvé vált, termelékenysége látványosan emelkedett.

A feldolgozóipari múveletek növekvő része vált automatizálhatóvá azzal, hogy a feldolgozási folyamat során szükséges beavatkozásokat is kodifikálták. A folyamatok során a paraméterek változását nem a folyamatról rejtett tudással rendelkezó szakmunkások felügyelik, hanem számítógépek mérik. Egy példa: korábban az acélipari szakmunkások a folyékony acél sæinérôl meg tudták állapítani az acél hömérsékletét. Ma számítógép jelzi, hogy mikor éri el az acél a soron következó múvelethez ssükséges hömérsékletet.

A számítógépes tervezốrendszerek magát a tervezési folyamatot tették rutinszerúvé, a már létezó megoldások tárolásával és a tervezés automatizálásával megkönnyítették, hoĝy a tervezốk magára a kreatív feladatra koncentráljanak.

Ami a vállalati múködéshez kapcsolódó adminisztratív tevékenységeket illeti, gondoljunk a vállalatokat, azok beszállítóit és vevôit összekötố elektronikus adatcserére (EDI) ami látványosan növelte az ü:lethez kapcsolódó adminisঞtráció hatékonyságát (rendelés, annak visszaigazolása, a rendelés nyomon követése, árazás, számlázás, pénzügyi elszámolás stb.). Az elektronikus adatcsere rendszerében még meglévö nehézkességeket és rugalmatlanságot ${ }^{9}$ a vállalati intranet és extranet rendszerek gyors elterjedése küszöbölte ki.

A technológia fejlôdése megváltoztatta a cégek internalizációs stratégiáját. ${ }^{10} \mathrm{~A}$ tranzakciós (koordinációs) költségek csökkenésének hatása nem egyértelmú: a vertikális integráció csökkenése és növekedése egyaránt levezethetô következmény. Csökkenô koordinációs költségek mellett, a cégek könnyebben diverzifikálhatják tevékenységüket, az új tevékenységek elvégzésére további leányvállalatokat alapíthatnak, növelve a szervezeten belül integrált, „házon belül végzett” tevékenységek számát. ${ }^{11}$ Ugyanakkor az is könnyebbé vált, hogy a korábban házon belül létrehozott félkész-termékeket a vállalatok immár a piacról, külsố beszállítótól szerezzék be.

A tapasztalatok azt mutatják, hogy az információtechnológiai forradalom hatására végsố soron csökkent a szervezetek vertikális integrációja, az integrált vállalatok elkezdték kiszervezni a korábban házon belül végzett tevékenységeik egy részét. Hitt (Hitt, 
1999) tanulmánya szoros negatív összefüggést mutatott ki a cégek informatizáltsága (az információtechnológiai berendezések és szoftverek értéke, az ún. információtechnológiai tốke) és a vertikális integráció foka között. Számításai szerint, az informatizáltság növekedése a vertikális integráció csökkenésével járt. Az információtechnológiai tôke ugyanis önmagában nem javítja a vállalati teljesítményt: az IT-beruházások stratégiai, üzleti értéke, termelékenységre gyakorolt hatása attól függ, hogy milyen kiegészítô vállalatszervezetiés menedzsment-innovációk kísérik ezeket a beruházásokat.

Aะ immateriális javak értékét növelő kiegészítő beruházások hatásával maǵyarázhatjuk azoknak a meghatározott mintákon ökonometriai módszerekkel tesztelt becsléseknek $\alpha \approx$ elsố látásra megäöbbentô eredményét, (Brynjolfsson \& Hitt, 2000) miszerint eǵy dollár értékú beruházás egy vállalat információtechnológiai tôkéjébe, kb. öt dollárral növeli $a$ z adott vállalat piaci értékét. Ha ez önmagában így igaz lenne, puszta informatikai beruházásokkal el lehetne érni, hoǵy az amerikai tôzsde tartósan szárnyaljon. A pussta informatikai beruházások mellett, azonban valamilyen módon számba kell vennünk az azokat kiegészitó, eǵyéb immateriális beruházásokat is. Induljunk ki abból a példából, hogy egy komplex vállalatirányítási rendszer bevezetésének sokmillió dolláros költségei kb. egy az öt arányban osslanak meg a hardver- és szoftver-költségek, illetve a rendszer bevezetéséhez és múködtetéséhe: szükséges, a vállalatszervezetet és a munkafolyamatokat érintő tanácsadás költségei között (Brynjolfsson et al., 2002). Számoljunk továbbá azzal is, hogy a szervezeti tóke növekedése esetlegesen és gyakran komoly késleltetéssel nyilvánul meǵ a vállalat értékének növekedésében, és így már elfogadhatóbbnak tûnnek az ökonometriai vizsgálatokkal alátámasstott fenti becslések.

A tevékenység informatizáltsági szintjének növekedését tehát egyfelôl a tevékenység értéklánc menti feldarabolódása kísérte (mint vállalatszervezeti innováció), másfelől az egyes tevékenységelemek, illetve az ezeket a tevékenységeket végző cégek hálózatokat alkottak. Az értéklánc felszeletelődése és a hálózatosodás ugyanannak az éremnek a két oldala.

A hálózatosodás vállalatszervezeti forradalmát - amelyet Langlois (Langlois, 2002) az „(újra) eltûnô kéz” idôszakának beszédes formulájával írt le - a technológia fejlődése tette lehetővé.

Langlois leírásából a "gazdaságot irányító kéz" láthatóságának ciklikus mozgása rajzolódik ki: hol a piaci, hol a hierarchikus koordinációs formák kerülnek túlsúlyba. A klasszikus kapitalizmus idôszakát az Adam Smith-i ${ }^{12}$ „láthatatlan kéz” formulával írhatjuk le: a meghatározó koordinációs forma a piaci koordináció. Késôbb Alfred Chandler (Chandler, 1977 és 1990) a „kéz láthatóvá válását” dokumentálta, mint az amerikai kapitalizmus alapvető jellemvonását a tömegtermelés időszakában. A vertikálisan integrált, sokdivíziós, multinacionális vállalatokon belül nem érvényesülnek a szabadpiaci mechanizmusok: a menedzseri hierarchikus koordináció, a "látható kéz" a nemzetközi kereskedelemnek, így értelemszerûen a globális termelésnek is növekvố hányadában van jelen: a nemzetközi kereskedelem körülbelül eǵyharmada vállalaton belüli kereskedelem.

A látható kéz irányította tevékenységhhányad növekedését az új üzleti modell, a hálózatosodás elterjedése állítja meg. A személyes tömegtermelés (Szabó \& Kocsis, 2002) idôszakában uǵyanakkor a vertikális struktúrák felbomlanak, és immár eǵy-eǵy vállalati 
funkcióra specializált, többé-kevésbé autonóm gazdasági szereplők kapesolódnak egymáshoz piaci alapon. Bonyolult szervezeti struktúrák jöttek létre, amelyben vertikális és horizontális elemek keveredtek.

\section{Hálózatosodás és hierarchia a felzárkózó országokban}

Az információtechnológiai forradalmat kísérő, gyorsan elterjedô vállalatszervezeti innováció: a hálózatosodás idôszakára esik a világgazdaság centrumán kívüli országok világgazdasági nyitásának új hulláma, a kereskedelmi és a múködőtőke-befektetésekre vonatkozó szabályozási politikájuk látványos liberalizációja, ezen országok világgazdasági integrációja. Így a kilencvenes években nem csupán fokozódott az egyre komplexebbé vált értékláncok dezintegrációja, de az értéklánc egyes pontjai földrajzilag jóval decentralizáltabban helyezkednek el.

A földrajzi decentralizálódással növekedett a hálózatokon belüli koordináció heterogenitása. A heterogenitást az is erôsítette, hogy az új üzleti modellben a hálózat egyes tagjainak hálózati státusa, pozíciója idővel módosulhatott. Míg a - vertikális integráción alapuló specializáció statikus szemléletû: az értéklánc minden egyes eleméért a hierarchia szigorúan meghatározott pontjain lévő szereplók felelősek, a dinamikus szemlélettel értelmezhetô hálózatokban az egyes szereplók pozíciója és feladatköre egyaránt változhat.

A nemzetközi üzleti- és menedzsment irodalom az értéklánc alapú hálózati szerveződés két, viszonylag homogén altípusát különbözteti meg: a japán és az amerikai típust. (Sturgeon, 2002) A japán típusú ún. „fogoly” hálózatokban a beszállítók kevés számú (gyakran egyetlen) megrendelőtől függnek. A beszállító-megrendelố kapcsolat szoros kötôdést, a beszállító részérôl sok olyan komoly volumenú beruházást igényel, ami kizárólag az adott relációban tud megtérülni. A megrendelő ugyanakkor szintén számos módon bizonyítja az adott kapcsolat iránti elkötelezettségét. A két fél között gyakran tőkebefektetői, tulajdonosi kapcsolat van, de - még független beszállítók esetében is - a megrendelôk gyakran technológiaátadással, esetenként termelố berendezések használatba adásával és technikai konzultációval, a megrendelő által igényelt minőségbiztosítás rendszer kiépítéséhez nyújtott segítséggel biztosítják, hogy a szállított termékek a megrendelố igényeit kielégítsék.

Az amerikai, ún. „kulcsrakész”, vagy moduláris hálózatok beszállítói ezzel szemben megrendelőjüktôl gyakorlatilag független, a megrendelővel szerződéses, piaci kapcsolatban álló, de egyidejüleg számos más megrendelőnek is szállító cégek. Az értéklánc alapú hálózati szerveződés amerikai altípusa onnan kapta a „kulcsrakész” elnevezést, hogy a beszállítók megrendelőiknek komplex gyártási szolgáltatást nyújtanak, vagyis a szállítandó termék teljes körû menedzseléséért felelősek. Ốk alakítják ki a termék design-ját, ốk fejlesztik ki a gyártástechnológiát, beszerzik a gyártáshoz szükséges inputokat, gyártanak, csomagolnak, megtervezik és menedzselik a termelésük belsổ és külsố logisztikai rendszerét, stb. Az értéklánc moduláris felépítésú, a megrendelốk rendszerintegrátorokként menedzselik a vállalati tevékenységet.

A fenti két értéklánc-alapú hálózati szerveződés-típus természetesen sem Japánban, sem az Egyesült Államokban nem jelenik meg a maga tiszta formájában, teljesen homogén módon. A multinacionális hálózatok már korábban is némi heteroge- 
nitást mutattak, amerikai és japán típusú koordinációs elemek keveredtek bennük, ám a világgazdaság centrumán kívüli országok világgazdasági nyitásának és integrálódásának, valamint az értékláncok fokozott dezintegrációjának következményeként az értéklánc alapú hálózati szervezôdések heterogenitása jelentôs mértékben növekedett. A világgazdaság centrumán kívüli, újonnan integrálódó országok gazdasági szereplői „fogoly” típusú szerveződési jellemzőket vittek a „kulcsrakész” alapon szerveződő hálózatokba.

A felzárkózó országok elméleti és gazdaságpolitikai szakirodalma a fenti jelenségeket a hálózatosodásos modernizáció szempontjából vizsgálja. Az elemzők szeme előtt ugyanakkor sokkal inkább az amerikai típusú szerveződésből adódó lehetőségek lebegnek, mint a japán típusúé. A hálózatosodás fogalmának egyik értelmezésébôl kiindulva az elemzők általában azt a kérdést veszik nagyító alá, hogy a multik helyi leányvállalatai képesek-e, hajlandók-e helyi hálózatokat létrehoঞni, helyi cégek válhatnak-e a Magyarországon megtelepedett multik beszállítóivá. (Csáki, 2001, Szanyi, 2001) Jelen tanulmány szerzője ezzel szemben abból indul ki, hogy a strukturális modernizáció kezdeti szakaszában, a hálózatosodásos modernizáció fố hajtóereje nem a globális szereplôk helyi hálózat-kialakítási hajlandósága, hanem a helyi szereplốk globális hálózatokba való bekapcsolódási képessége.

A modernizáció későbbi szakaszaiban a helyi hálózatok kérdése egyre hangsúlyosabb gazdaságpolitikai célkitûzéssé vált. A gazdaságpolitikai döntéshozóknak azonban rá kellett döbbenniük arra, hogy bizonyos iparági sajátosságokkal rendelkezố iparágakban ${ }^{13}$ a mégoly erôteljes és kreatív gazdaságpolitikai ösztönzők sem vezetnek eredményre, nem formálódnak helyi hálózatok, a technológia helyi diffúziója nem halad előre. A helyi hálózatok kialakítására tett erőfeszítések sorozatos kudarcai ellenére sem vonhatjuk le azt a következtetést, hogy ezekben az iparágakban kizárólag vertikális integráción alapuló hálózatok képzelhetốk el. Ellenkezôleg, az informatikai feldolgozóipar hálózataiban számos moduláris, horizontális szervezôdésú elemet találunk, ${ }^{14}$ csak éppen nem az újonnan integrálódó, felzárkózó országok feldolgozóipari szereplőinek körében. Az ezekben az országokban található hálózati szereplők nem az amerikai modell független, kulcsrakész alrendszerszállítói, akik maguk felelősek saját beszállítóikért, az általuk kialakított helyi hálózatokért. A felzárkózó országokban múködő, újonnan a hálózatokba integrálódott szereplők japán típusú beszállítók: szigorú hierarchikus rend alján lépnek be a hálózatokba, és modernizációjuk, sốt fennmaradásuk egyetlen esélye, az integrálódás.

A feldolgozóipari értékláncokat többszörös hierarchia-szintekból álló globális hálózatként kell elképzelnünk. A hierarchia csúcsán lévő rendszerintegrátorokhoz kapcsolódó hálózati szereplők hálózati szerveződésére valóban az amerikai típusú modularitás jellemző. A hierarchia alján lévô, az alrendszer-integrátorokhoz kapcsolódó beszállítók azonban (ide tartozik a világgazdaság centrumán kívül fekvô országok újonnan integrálódott feldolgozóipari cégeinek döntő többsége) a japán „fogoly” típusú hálózati szerveződéssel integrálódnak.

Szögezzük le: a japán típusú hálózati szervezôdés tényének rögzítése semmiképpen sem jelent negatív értékítéletet, hiszen a felzárkózó országok modernizációjában a hangsúly az integráción van! A tranzakciós költségeket, fơként a keresési, koordinációs és információátadási költségeket látványosan csökkentô információtechnológia lehetôséget teremtett a periférián elhelyezkedő szereplők integrálódására, arra, 
hogy a globálisan kialakított és menedzselt hozzáadott értékláncok létrehozásához maguk is hozzájáruljanak. Ez az integrálódás azonban értelemszerûen nem a „kulcsrakész" típusú hálózati szervezôdés mintájára történt, hiszen a hálózatba kapcsolódáshoz komoly technológiai és üzemszervezési tanulásra volt szükség. Az integrálódáshoz nélkülözhetetlen transzferekhez kizárólag a mûködôtốkét fogadó, a hálózatokba vertikálisan integrálódó szereplốk jutottak hozzá.

Az előbbiekben bizonyítani próbáltuk, hogy a felzárkózó országok gazdasági szereplôii is bekapcsolódtak a hálózati szervezôdésű globális értékláncokba. Szükségszerû́nek láttuk, hogy a múködôtốke-befektetések segítségével modernizálódni igyekvő országok hálózatosodására a japán, fogoly típusú hálózati szerveződés jellemző. Ha azonban a hálózati szerveződés dinamikus jellemvonásaiból indulunk ki, abból, hogy a hálózatokban az egyes szereplôk pozíciója és feladatköre egyaránt változhat - fel kell tennünk azt a kérdést, hogy van-e átjárás a két szerveződési típus között? Mérséklődik-e idővel a hierarchia? Megfigyelhetô-e a hálózatok periferikus szereplői esetében is az a számos tanulmányban elemzett ${ }^{14}$ jelenség, miszerint a hierarchikus szerveződésen alapuló kapcsolatok egyre inkább átadják a helyüket a decentralizált döntéshozatalra, kooperációra és nem parancsteljesítésre, bizalomra és kölcsönösségre épülő, horizontális, hálózati szerveződésú formáknak?

\section{A piaci koordináció térnyerése - A periféria kimarad?}

A nemzetközi üzleti- és menedzsment-irodalom visszatérô megállapítása, hogy az információs- és tudásgazdaságban a vállalatszervezet átalakul, módosulnak a vállalati határok ${ }^{15}$ - részben a piaci és a hierarchikus koordináció összetételének, az egyes koordináció-típusok előfordulási gyakoriságának módosulása következtében. A tudásgazdaságban a vállalatok a tevékenységükhöz szükséges tudás egyre nagyobb részét kívülrôl, a tulajdonviszonyok által meghatározott vállalati határaikon kívül kénytelenek megszerezni. A gazdasági tevékenység keretei emiatt már nem szükségszerúen esnek egybe a vállalati határokkal: a tevékenységek szervezôdési kereteit a tudáshálózatok (meghatározott tudáselemek birtokosai alkotta hálózatok) alkotják. ${ }^{16}$ Minél speciálisabb szaktudást igényel egy-egy tevékenység, minél speciálisabb szaktudással rendelkező foglalkoztatottak végzik azt, a tevékenység megszervezésének annál kevésbé célravezetố módszere a termelố berendezések (vállalati részvények) tulajdonjogán alapuló hierarchikus koordináció. (Helper et al., 2000)

A hálózatosodás és a decentralizáltabbá váló döntéshozatal következményeként a vállalati múködés egyre több területén piaci, pontosabban kvázi piaci tranzakciók terjedtek el és szorították ki a hierarchikus, bürokratikus döntéseken alapuló tranzakciókat. ${ }^{17}$ A tranzakciók „piacosodása” egyrészt a tevékenység mind több elemének kiszervezésére vezethetô vissza, másrészt arra, hogy míg korábban a vállalat egyes divíziói vagy leányvállalatai közötti munkamegosztás a bürokratikus hierarchia döntései alapján alakult ki, ma ez már egyre inkább piaci jellegú verseny eredményeként szerveződik.

Kvázi piaci verseny folyik a vállalatokon belül az egyes divíziók, multinacionális cégek esetében az egyes leányvállalatok között, az éves költségvetések és tervek jóváhagyása idején a beruházási, fejlesztési forrásokért, továbbá belsô verseny indulhat 
egyes megürült vállalati pozíciókért. Kvázi piac alakult ki a vállalatokon belül az újonnan fejlesztett termékek gyártási jogáért.

A multinacionális cégek szabályos telephely-tenderpályázatot írnak ki leányoúllalataik körében. A gyártási jog megszerzéséért beadott ajánlatok elbírálása aะ ár; a szállitási pontosság és a minóségi paraméterek alapján történik. Az egyik legfontosabb minóségi paramétert az képezi, hogy a gyártás mellett milyen eǵyéb gyártáshoz kapcsolódó szolgáltatást vállal a versengó leányvállalat. Az ajánlat részét képezik a projekt megvalósításához szükséges beruházások is: a „pályázó” ismerteti a projekt megvalósításához nélkülözhetetlen technológia-fejlesztési, képzési, és logisztika-fejlesঞtési elképzeléseit, ezek költségivonzatát. Ajánlatot uǵyanis nem csupán az a leányoállalat tehet, amelyik rendelkezik az adott termék gyártásához szükséges berendezésekkel, a fejles»téshez szükséges $K+F$-bázissal, tes:tberenderésekkel.

A gyártás jogáért a vállalaton belül folytatott versenyt a leányvállalatok ugyanolyan komolyan veszik, mint a külső projektek elnyerésért folytatott versenyt: a részvétel ugyanolyan múszaki ajánlattételi, projekt tenderpályázat-írási képességeket igényel. Az újonnan fejlesztett termékek gyártási jogának elnyerése több okból is létkérdés a helyi leányvállalatok fejlődése szempontjából. Egyrészt, az elnyert projektek függvényében növekedhet a helyi leányvállalat, ettôl függ, hogy sor kerül-e beruházásokra, technológia-fejlesztésre, vagy sem. Másrészt, ettôl függ a meglévố kapacitások kihasználása is, hiszen, ha egy helyi leányvállalat nem nyeri el időről-időre az új technológiát képviselố termékek gyártási jogát, a kifutó termékek iránt folyamatosan csökken a kereslet, így a helyi kapacitás kihasználatlan marad. A helyi leányvállalat menedzsmentjének (csakúgy, mint az anyavállalaténak) így alaposan meg kell gondolnia, hogy meddig és milyen ütemben növekedjen a helyi leányvállalat, vagyis milyen életciklus-menedzsment stratégiát kövessen annak érdekében, hogy a kapacitásai hosszabb távon is egyenletesen ki legyenek használva.

Épp ezért csak részlegesen van igaza Töröknek (Török, 2001), aki szemléletes példával igyekezett bizonyítani, hogy napjainkban egy-egy helyi leányvállalatnak meglehetősen korlátozott versenyben kell helytállnia, illetve egy-egy felzárkózó ország versenyképességét, teljesítményét egyszeri események hosszabb távon meghatározhatják:

„Gondoljunk arra: a mai maǵyar export néhány sikeres terméke, sikeres termékcsoport$j a$, vagy sikeres cége, például $\alpha$ \& Audi és aะ IBM magyarországi leányoállalata magyar szempontból mennyire igazi versenyben mérettetik meg? Mindkettố egy zárt, vállalaton belüli beszállitói rendszernek az egyik végpontja Maǵyarországon, és annak a vállalatnak a vállalaton belüli értékesítési csatornáin szállít ki Németorsáǵgba. A maǵyar telephely versenyképességének ez a kérdése eldólt akkor, amikor est a telephelyet az IBM vaǵy az Audi kiválasstotta." (Török, 2001:9)

Valójában, a transznacionális szervezeteken belül egyes leányvállalatok felemelkedése és hanyatlása gyakori esemény. 
Birkinshaw (Birkinshaw, 1998) tanulmánya felállítja a multinacionális cégen belüli verseny modelljét. Hipotézise szerint a vállalati központ felelósségi köre „támadható”, az egyes leányvállalatok magukhoz ragadhatnak olyan funkciókat, amelyek átadása a multi hálózatát optimalizálja. Ebben a modellben a feladat- és felelősségi köröket időról-időre újraelosztják az anyavállalat szervezetén belül. Az újraelosztás azért lehetséges, mert a multinacionális szervezet alegységeinek teljesítményét napjainkban már rendszeres időközönként összehasonlítják egymással (internal benchmarking).

A vállalaton belüli kvázi piacok létét és a hierarchikus tranzakciók piacosodásának elméletét erôs szkepszissel szemléli Hodgson (Hodgson, 2002). Tanulmánya szembehelyezkedik a lassanként „mainstream”-mé váló fenti megfontolásokkal. Bizonyítani igyekszik, hogy a vállalaton belüli tranzakciók piacosodásának jelenségei ellenére a koordináció végsố soron hierarchikus maradt. Ami az egyes megürült pozíciók belső megversenyeztetését illeti, szerinte ezek az egyszeri alkalmak nem hasonlítanak az igazi munkaerôpiac folyamatos és tömeges, több vevő és eladó jellemezte kereslet-kínálati viszonyaira. Ami a beruházásokért folytatott „piaci versenyt” illeti, Hodgson szerint ez inkább a hatalomért és forrásokért folytatott verseny a vállalati bürokrácia különbözô csoportjai között. Hiába versenyeztetik meg a leányvállalatokat beruházási, fejlesztési forrásokért, vagy egyes résztevékenységek végzési jogáért, a döntést végső soron mégis a vállalati bürokrácia hozza meg, méghozzá nem kizárólag „belső piaci jellegú” megfontolások alapján.

Jelen dolgozat szerzôje egyetért ugyan Hodgson állításának utolsó részével, miszerint a piaci tranzakciók mintájára történó belső versenyeztetést követôen, a döntést esetleg hierarchikus és nem feltétlenül piaci logika szülte megfontolások alapján hozza meg a vállalati központ, Hodgsonnál mégis jóval kevesebb szkepszissel ismeri el a vállalati tranzakciók piacosodásának, a termelési inputok tulajdonjogán alapuló hierarchia mérséklôdésének tényét. A lazább, horizontális szervezôdési formák azonban nem érvényesülnek automatikusan a hálózatok minden egyes tagja esetében. Hipotézisünk szerint, egy-egy vállalati hálósatban eltéró koordinációs formák, a hierarchia eltéró fokozatai léteznek egymás mellett. A koordinációs módszer hierarchia-fokát az határozza meg, hogy a hálózat adott tagja tevékenységének megszervezéséhez mely rendszerintegrátori funkcióra van elsősorban szükség.

A multinacionális vállalati központok ugyanis a stratégiaalkotáson túlmenően kettôs feladatkört látnak el. „Új gazdaság”-jellegú rendszerintegrátori funkcióik közé tartozik a földrajzilag szétszórt tudás felismerése, megszerzése, koordinálása és optimális hasznosítása. Másrészt, továbbra is alapvetố rendszerintegrátori funkció maradt a vállalati produktumok hatékony előállításának megszervezése és menedzselése. Mig a tudás koordinációja az egyéb termelési inputok tulajdonjogán alapuló hierarchikus koordinációtól eltérö autoritást és össtönzőket igényel, a vállalati produktumok hatékony elöállitásának megszervezéséhez továbbra is hierarchikus koordinációra van szükség.

Összefoglalva, a második fejezetet bevezetô kérdésekre a következố válaszokat adhatjuk: A hierarchia mérséklődése, a horizontális, kooperatív kapcsolatrendszer kialakulása nem azért marad el a világgazdaság centrumán kívül fekvő, de jó hálózatosodásos modernizációs teljesítményt mutató országok gazdasági szereplôi többségének körében, mert ezek a szereplő́k a globális hálózatok periferikus tagjai. A kapcsolatrendszer hierarchia-foka elsôsorban a(z értékláncon belüli) funkció és nem 
a hálózati pozíció függvénye, bár természetesen a funkció és a pozíció egymással szoros összefüggést mutat. Magyarán, a világgazdaság centrumában (például a volt keletnémet tartományokban, vagy Írországban) elhelyezkedô, termelő leányvállalatok hálózati szerveződése éppolyan hierarchikus jellemvonásokat mutat, mint a periférián, például egy thaiföldi településen elhelyezkedő termelő leányvállalaté. Egy periférián (például egy kelet-közép-európai országban) elhelyezkedô fejlesztô központ, vagy egy latin-amerikai marketing- és kereskedelmi központ hálózati szerveződését ezzel szemben sokkal inkább kooperatív, bizalomra és kölcsönösségre épülő, kevéssé hierarchikus, horizontális jellemvonásokkal írhatjuk le, vagyis esetükben a hierarchikus koordináció kevésbé jellemzô, mint ugyanazon a hálózaton belül a termelő vállalatokra.

Ami a hierarchikus, japán és a horizontális, kooperatív, amerikai szerveződési modell közötti átjárást illeti, egy-egy helyi cég számára kizárólag abban az esetben adódik erre lehetôség, ha a cég diverzifikálja, vagy módosítja korábbi (puszta termelői) funkcióját (lásd errôl [Szalavetz, 1999]), vagyis a termelés mellett a vállalati tevékenységhez, vagy a termékekhez kapcsolódó szolgáltatásokat is vállal. Egy-egy nemzetgazdaság szintjén is elképzelhetô átjárás, amennyiben növekszik a globális hálózatokba horizontálisan kapcsolódó, vagy/és az amerikai hálózati szerveződési modell jellemvonásait mutató szereplők száma, GDP-hozzájárulása. Melyek ezek a szereplő́k? Ebbe a csoportba tartoznak a multinacionális vállalatok helyi fejlesztô központjai (illetve a helyi $\mathrm{K}+\mathrm{F}$-szervezettel is rendelkező, vagy a termelés mellett egyéb vállalati funkcióra is szakosodott termelổ leányvállalatai), a globális hálózatokba kapcsolódó stratégiai üzleti szolgáltatásokat nyújtó cégek, valamint a komplex termelési szolgáltatást nyújtó multinacionális cégek helyi leányvállalatai. ${ }^{18}$ A gazdaság szerkezeti modernizációja, a stratégiai üzleti szolgáltatások GDP-részarányának növekedése így értelemszerûen a horizontális, kevéssé hierarchikus hálózati szervezôdés térhódításával jár együtt.

\section{JEGYZETEK}

* A szerző köszönettel tartozik Kapás Juditnak a cikk elsố változatához füzött észrevételeiért.

1 Az „új gazdaság” különbözô értelmezéseiról lásd: Szalavetz (Szalavetz, 2002.a)

2 A szerződéses vállalatelméletek egyik ágát képezik az erôforrás alapú vállalatelméletek. (Kapás, 1999.b)

3 Kapás (Kapás, 1999.a és b) átfogó áttekintést ad az egyes vállalatelméletekról.

4 „Egyéni” alatt akár egy transznacionális vállalat méretú szervezetet is érthetünk.

${ }^{5}$ Egyes fordítások szerint magkompetencia, vagy alapkompetencia. Jelen tanulmány szerzője a kulcskompetencia kifejezést preferálja, az alapvetô, vagy kulcsfontosságú kompetencia rövidítéseként.

${ }^{6}$ A termelést megelőző, az azt követő és az értéklánc minden egyes pontján fontos szerepet játszó szolgáltatások.

7 Az Intel 1998-as múködőtốke-befektetését követően látványosan növekedett Costa Rica informatikai feldolgozóipari kibocsátása, exportja és a szektorban foglalkoztatottak száma. „Blue chip” informatikai cégek, mint az Acer, Microsoft, Motorola, Cisco, Seagate, Hewlett Packard nyitottak helyi termelố leányvállalatokat és számos beszállítójuk is követte ôket. Az 
Intel-befektetésnek köszönhetô (vagyis erre az egyetlen cégre visszavezethetô) csúcstechnológiai export az összes export 25,1 \%-át tette ki 2000-ben. (Forrás: UNCTAD World Investment Report 2002, 168. lap)

8 A kifejezést Balassa (Balassa, 1967) vezette be a köztudatba. A kelet-közép-európai országok vertikális specializációját Landesmann és Burgstaller (Landesman \& Burgstaller, 1997) elemezte, Hummels és szerzôtársai (Hummels et al., 2001) pedig 14 ország input-output adatai alapján átfogó számításokkal dokumentálták a vertikális specializáció növekedését 1970 és 90 között.

9 A technológia kiépítése meglehetősen költséges volt, továbbá az ilyen módon egymással kommunikáló szereplőknek szigorú formai szabályokat kellett betartaniuk (az elektronikus dokumentumok formatálásakor számos szabályt kellett figyelembe venni). Mindez korlátozta az ilyen módon hálózatba kapcsolt szereplő́k fluktuációját, új szereplốk belépését.

${ }^{10}$ A vállalati stratégia egyik alapvető döntése, hogy bizonyos erőforrások létrehozását a cégek saját kompetenciájukra támaszkodva szervezzék meg, vagy a piacról jussanak hozzá, netán valamilyen a piac és a hierarchia közötti köztes megoldást alkalmazzanak (például stratégiai szövetségek, hosszú távú szerződések, licenckapcsolatok stb.)

${ }^{11}$ Egyes szerzốk szerint (Langlois, 2002), a konglomerátumok kialakulása nem fokozódó integrációt jelent, hanem éppen hogy egyfajta elsổ lépést a dezintegráció irányába. A holding szervezet alatt tömörülő, számos különféle iparágba tartozó leányvállalatok létrejötte, a moduláris szervezet megvalósításának irányába tett első lépésként értelmezhető.

${ }^{12}$ Adam Smith, 1976 An Enquiry into the Nature and Causes of the Wealth of Nations. Glasgow Edition, Oxford: Clarendon Press - első kiadás: 1776)

${ }^{13} \mathrm{Az}$ informatikai feldolgozóipar iparági sajátossága, hogy ezeknek az ágazatoknak a képviselői globálisan integrálják beszerzési hálózatukat, nem keresnek helyi beszállítókat. (Belderbos \& Capannelli, 2001) Más globális iparágak esetében (például autóipar) a helyi hálózat-kialakítási hajlandóság nem ennyire alacsony, az ő esetükben a helyi hálózatok kialakítása, a technológia lokális diffúziójának elốsegítése releváns gazdaságpolitika kihívás.

${ }^{14}$ Sôt, épp az informatika és az elektronika az a két iparág, amelyben már a nyolcvanas évek végétôl kezdve látványos gyorsasággal nôtt mind a komplex gyártási szolgáltatásokat igénybevevő, a gyártási tevékenységet ilyen módon kihelyezô, mind a gyártási szolgáltatást nyújtó cégek száma. Ez utóbbiak jövedelme a kilencvenes években meredeken emelkedett: 1988ban a 20 legnagyobb gyártási szolgáltatást nyújtó cég összes árbevétele 1683 millió dollár volt, 1995-ben 12445 millió dollár (Sturgeon 1998:6). A Contract Manufacturing Consultants jelentése szerint 2001-ben több mint 50 olyan gyártási szolgáltató volt az elektronikai szektorban, amelynek az árbevétele meghaladta a 100 millió dollárt. (http://www.cmc-inc.net/industry_research.htm)

${ }^{15}$ Lásd például: Foss (Foss, 2002); Mendelson \& Pillai (Mednelson \& Pillai, 1999); Grandori (Grandori, 2002)

${ }^{16}$ Powell és szerzốtársai (Powell et al., 1996) például a biotechnológia-iparban végeznek vizsgálatokat azt bizonyítandó, hogy komplex és gyorsan növekvố tudásállománnyal rendelkezô iparágakban, alapvetően nem egy-egy cég keretein belül jönnek létre innovációk, hanem több cég alkotta tudáshálózatokban.

${ }^{17}$ A vállalatokon belüli kvázi piacok fố teoretikusa Benjamin Klein (Klein, 1983), aki még a modern vállalatelmélet egyik fő teoretikusát, a piaci és hierarchikus (vállalaton belüli és vállalatok közötti) tranzakciókat korábban mereven elválasztó Coase-t is megállapításainak újragondolására késztette. 1988-as tanulmányában Coase elismerte, hogy legújabb tapasztalatai valóban bővelkednek a vállalatokon belüli piaci jellegú múködés példáiban. Mint legfurcsább 
esetet, az angol állami tulajdonban lévő áramszolgáltató cég esetét elemezte, amely aukciós alapon múködve, azoktól a regionális áramszolgáltatóktól vásárolja az áramot, amelyek a legalacsonyabb áron hajlandók szállítani azt. Coase ebben a tanulmányban elismerte, hogy a vállalatelmélet és a piac elméletének merev elkülönítése napjainkban már erôsen torzítaná az elemzések szemléletét.

A vállalatelmélet magyarországi képviselője (Kapás, 2002), két jól azonosítható trendet ír le a hibrid koordinációs struktúrák elemzésekor: a hierarchia behatolását a piacba, illetve a piac behatolását a hierarchiába. „A 'piacnak' illetve 'vállalatnak' nevezett (koordinációs) formák tartalma átalakult, hiszen a 'vállalat' piacszerúbbé, a 'piac' pedig vállalatszerúbbé vált." - írja. (Kapás, 2002:329)

${ }^{18}$ Magyarországon ilyen például a Flextronics, amelynek helyi leányvállalatai, gyártóbázisai intenzív vállalati tanulás révén mind elindultak a komplex gyártási szolgáltatóvá válás útján.

\section{IRODALOM}

Balassa, B. (1967): Trade Liberalization Among Industrial Countries. McGraw-Hill, New York Belderbos, R. \& Capannelli, G. (2001): Backward Vertical Linkages of Foreign manufacturing Affiliates: Evidence from Japanese Multinationals. World Development vol. 29, No. 1

Birkinshaw J. (1998): Subsidiary initiatives to develop new markets. Sloan Management Review, Spring, vol. 39, No.3

Birkinshaw, J. \& Sheehan, T. (2002): Managing the knowledge life cycle: knowledge isn't static, but it often gets managed as if it were. MIT Sloan Management Review, vol. 44, No.1

Brynjolfsson, E. \& Hitt, L. M. (2000): Beyond Computation: Information Technology, Organizational Transformation and Business Performance. Journal of Economic Perspectives, vol. 14, No. 4

Brynjolfsson, E. \& Hitt, M. L. \& Yang, S. (2002): Intangible Assets: Computers and Organizational Capital. Brookings Papers on Economic Activity, No. 1

Castells, M. (2000): The Network Enterprise: the Culture, Institutions, and organizations of the Informational Economy. In: The Rise of the Network Society. $2^{\text {nd }}$ edition, Blackwell Publishers, Oxford, UK, pp. 163-215

Chandler, A. D. Jr. (1977): The Visible Hand: the Managerial Revolution in American Business. Cambridge: The Belknap Press

Chandler, A. D. Jr. (1990): Scale and Scope: the Dynamics of Industrial Capitalism. Cambridge: The Belknap Press

Coase, R. H. (1988): The Nature of the Firm: Origin, Meaning, Influence', Journal of Law, Economics, and Organization, Spring, vol. 4, No. 1

Csáki, Gy. (2001): Új tendenciák a nemzetközi múködôtốke-áramlásban és a magyar múködôtốke-importban. In: Csáki, Gy. (szerk.) Befektetésösztönzés és múködôtőke-bevonás. Lehetôségek az Európai Uniós Csatlakozás Előkészítésének Idôszakában. Oktatási Minisztérium, Budapest, pp. 9-41

Dunning, J. H. (1995): Reappraising the eclectic paradigm in an age of alliance capitalism. 
Journal of International Business Studies vol. 26, No. 3

Feenstra, R. C. (1998): Integration of Trade and Disintegration of Production in the Global Economy. The Journal of Economic Perspectives, Fall, 1998, vol. 12, No. 4

Foss, N. J. (2002): 'Coase vs Hayek': Economic organization and the knowledge economy. International Journal of the Economics of Business, vol. 9, No. 1

Grandori, A. (2002): Organizations and Economic Behavior. London, Routledge

Hagedoorn, J. (1993): Understanding the rationale of strategic technology partnering: internationalisation modes of cooperation and sectoral differences. Strategic Management Journal vol. 14, pp. 371-385

Helper, S. \& MacDuffie, J. P. \& Sabel, C. (2000): Pragmatic Collaborations: Advancing Knowledge While Controlling Opportunism," Industrial and Corporate Change, vol. 9, No. 3. Working paper változat: http://www.weatherhead.cwru.edu/faculty_research/homes/helper/pragcoll.pdf

Hitt, L. M. (1999): Information Technology and Firm Boundaries: Evidence from Panel Data. Information Systems Research, vol. 10, No. 2

Hodgson, G. M. (2002): The legal nature of the firm and the myth of the firm-market hybrid. International Journal of the Economics of Business, vol. 9, No. 1

Hummels, D. \& Ishii, J. \& Yi, Kei-Mu (2001): The nature and growth of vertical specialization in world trade. Journal of International Economics, vol. 54, No. 1

Kapás, J. (2002): Piacszerú vállalat és vállalatszerû piac. Közgazdasági Szemle, vol. 49, 4. szám Kapás, J. (1999.a): Szükséges-e többdimenziós vállalatelmélet? Közgazdasági Szemle, vol. 46, 9. szám

Kapás, J. (1999.b): Egy új vállalatelmélet: Erőforrás-alapú megközelítés. Összefoglalás és diagnózis. Vezetéstudomány, vol. 30, 2. szám

Klein, B. (1983): Contracting Costs and Residual Claims: The Separation of Ownership and Control", Journal of Law and Economics, vol. 26, No. 2

Krugman, P. (1996): Does Third World Growth Hurt First World Prosperity? Harvard Business Review, vol. 72, No. 4

Landesmann, M. \& Burgstaller, J. (1997): Vertical Product Differentiation in EU Markets: the Relative Position of East European Producers, WIIW Research Reports, No. 234.a, Vienna, WIIW

Langlois, R. N. (2002): The Vanishing Hand: The Changing Dynamics of Industrial Capitalism. Industrial and Corporate Change, vol. 12, megjelenés alatt. Working paper változat: http://www.econ.uconn.edu/working/2002-21.pdf

Lorenzoni, G. \& Lipparini, A. (1999): The leveraging of interfirm relationships as a distinctive organizational capability: a longitudinal study. Strategic Management Journal, vol. 20, No. 4

Mendelson, H. \& Pillai, R. R. (1999): Information Age Organizations, Dynamics, and

Performance. Journal of Economic Behavior and Organization, vol. 38, No. 3

Nonaka, I. \& Toyama, R. \& Nagata, A. (2000): A firm as a knowledge-creating entity: a new perspective on the theory of the firm. Industrial and Corporate Change, vol. 9, No. 1

Nonaka I. \& Takeuchi H. (1995): The Knowledge-Creating Company. New York, Oxford University Press

OECD (1999): Strategic Business Services. Paris, OECD

OECD (1996): Globalisation of Industry. Paris, OECD 
Powell, W.W. (1990): Neither market nor hierarchy: Network forms of organization. In:

Cummings, L. L. \& Staw, B. M. (eds.): Research in Organizational Behavior, 12: 295-336.

Greenwich, CT: JAI Press

Powell, W.W. \& Koput, K. W. \& Smith-Doerr, L. (1996): Interorganizational collaboration and the locus of innovation. Administrative Science Quarterly, vol. 41, No. 1

Prahalad, C. K. \& Hamel, G. (1990): The core competence of the corporation. Harvard Business Review, vol. 68, No. 3

Prahalad, C. K. \& Ramaswamy, V. (2000): Co-Opting Customer Competence. Harvard Business Review, vol. 78, No. 1

Ritter, T. \& Gemünden, H. G. (2003): The impact of a company's business strategy on it technological competence, network competence and innovation success. Journal of Business Research, vol. 56, megjelenés alatt

Sturgeon, T. J. (2002): Modular production networks: a new American model of industrial organization. Industrial and Corporate Change, vol. 11, No. 3

Sturgeon, T. J. (1998): Network-Led Development and the Rise of Turn-Key Production Networks: Technological Change and the Outsourcing of Electronics Manufacturing. http://globalization.mit.edu/Development.pdf

Szabó, K. (1998): Kihelyezési hullám. A piac térhódítása a vállalati hierarchiák rovására. Közgazdasági Szemle, 2 szám

Szabó, K. \& Kocsis, É. (2002): Digitális paradicsom vagy falanszter? A személyes tömegtermelés. Budapest, Aula

Szalavetz, A. (2002.a): „Új gazdaság” és gazdasági növekedés Magyarországon. Külgazdaság, 9. szám

Szalavetz, A. (2002.b): „Új gazdaság”-jelenségek - A feldolgozóipar tercierizálódása. Külgazdaság, 12. szám

Szalavetz, A. (1999): Magyar feldolgozóipari vállalatok a globalizáció sodrában. Külgazdaság, vol. 43,12 . szám

Szanyi, M. (2001): Stratégiai szövetségek és tartós vertikális kapcsolatok a magyar gazdaságban. Vezetéstudomány, vol. 32, 1. szám

Török, Á. (2001): A versenyképesség mérése és értelmezése. In: Verseny Európa küszöbén. ÁVF Tudományos Közlemények, 3. szám, Általános Vállalkozási Fôiskola, Budapest 